\title{
Management of Competitiveness of a Regional Agricultural Sector
}

\author{
Igor N. Goretov $^{1}$, Faina Z. Gumarova ${ }^{1} \&$ Evgeny I. Tsaregorodtsev ${ }^{1}$ \\ ${ }^{1}$ Mari State University, Yoshkar- Ola, Russia \\ Correspondence: Eveny I. Tsaregorodtsev, Institute of Economy, Management and Finance, Mari State \\ University, Komsomolskaja str. 117 ap. 30, Yoshkar- Ola, 424004, Russia. E-mail: evgts@marsu.ru
}

Received: February 21, 2015 Accepted: March 15, 2015 Online Published: April 29, 2015

doi:10.5539/res.v7n8p105

URL: http://dx.doi.org/10.5539/res.v7n8p105

\begin{abstract}
In the article questions of increase of competitiveness of agrarian sector of the region are considered. The special attention is paid to stimulation of investment activity of market subjects. The cluster analysis of production of major types of agricultural production in subjects of the Volga Federal Region is made. Measures for improvement of an investment and tax policy of agrarian sector are offered. Realization of the above stated measures will promote growth of competitiveness of the agrarian sector of the Mari EL Republic and solution of questions of import substitution in the Russian food market.
\end{abstract}

Keywords: agrarian sector, competitiveness, regional economy, cluster analysis, development strategy

\section{Introduction}

The current stage of development of the agricultural sector is characterized by new competitive features. If the main purpose of pre-sanctions period was exceeding of indicators of imported production in a number of parameters, the cardinal of which was the price level, then since the beginning of 2015 the center of competition has shifted to the regional level. Due to currency barrier to the internal market, if the food and agricultural sector gets products from new countries of South America and Asia, it will have to overcome the consumer inertial barrier. This time should be used by domestic manufacturers to win their share of the domestic market. The main obstacle is the sharp decline in access to investment resources, which significantly reduces the rate of import substitution in the regional agricultural sector.

A similar problem on a smaller scale our economy has faced in 2008, when the proportions of foreign and domestic currency sharply changed. A number of papers analyzing this process considered that problem not only by leading experts on a national scale, but also reflected its aspects for catch-up regions of the Volga Federal Region (Goretov, 2012; Smirnov \& Popova, 2011; Shvetsov, 2010). The main conclusions drawn from the results of the crisis overcoming, was aimed at creating and state support of cluster structures in the agricultural sector (Tsaregorodtsev, 2013), and first of all its financial security (Gumarova \& Kazakovtseva, 2014). While developing techniques of crisis overcoming it's important to use agriculture management experience in the leading countries, particularly in Canada and the United States (Bilson \& Darku, 2015; Rakhal \& Shashini, 2014).

\section{Materials and Methods}

Agro-industrial complex of the Mari El Republic is a leading system-economic sphere, forming the agri-food market, food and economic security, employment and settlement potential of rural areas. Republican target program "Development of agriculture and regulation of markets of agricultural products, raw materials and food in the Mari El Republic for 2008-2012" provided the growth of business activity in the agricultural sector of the republic and increase the investment attractiveness of this industry, increase in the volume of agricultural products and foodstuffs. Work on social development of rural areas was activated, and large agro-industrial units were developed.

The present level of development of agriculture of the Mari El Republicis is largely determined by the available natural resource potential - the existence of agricultural lands, the effectiveness of its usage and existing on the territory restrictions of agriculture, infrastructure security and institutional conditions of agro industry.

In the period of 2009-2013 an increase of agricultural production was observed; average annual growth rate during this period showed $8 \%$. The decline in agricultural production was recorded only in 2010, mainly due to 
adverse weather conditions (Sbornik, 2014).

Table 1. Agricultural output of all categories of households (at current prices, million rubles)

\begin{tabular}{|c|c|c|c|c|c|}
\hline & 2009 & 2010 & 2011 & 2012 & 2013 \\
\hline \multicolumn{6}{|l|}{ Agricultural products: } \\
\hline \multirow[t]{2}{*}{ at current prices } & 18 & & & & \\
\hline & 453.3 & 16461.8 & 21910.8 & 25194.4 & 30232.4 \\
\hline in $\%$ of previous year ${ }^{*}$ & 103.1 & 87.5 & 126.7 & 113.4 & 109.2 \\
\hline \multicolumn{6}{|l|}{ Crop production: } \\
\hline at current prices & 7690.3 & 6344.2 & 10720.0 & 11389.4 & 12984.0 \\
\hline in $\%$ of previous year ${ }^{*}$ & 109.0 & 63.6 & 168.9 & 107.6 & 99.3 \\
\hline \multicolumn{6}{|l|}{ Livestock products: } \\
\hline \multirow[t]{2}{*}{ at current prices } & 10 & & & & \\
\hline & 763.0 & 10117.6 & 11190.8 & 13805.0 & 17248.3 \\
\hline in $\%$ of previous year ${ }^{*}$ & 99.0 & 104.6 & 100.1 & 119.1 & 117.5 \\
\hline
\end{tabular}

* In the comparable estimation.

In the structure of agricultural production in all categories of households crop and livestock production share in 2009 accounted 41.7 and 58.3\%, in 2013-respectively 42.9 and 57.1\% (Sbornik, 2014, p. 15).

The main producers of agricultural products in 2009-2013 still were agricultural organizations and private households.

Most of the agricultural products produced in households - $49.6 \%$, the share of agricultural enterprises is $48.5 \%$, farms (peasant households), including individual entrepreneurs-1.9\% (Sbornik, 2014, p. 17).

Since 2012, in the Mari El Republic departmental target programs were implemented to support beginning farmers and to develop family livestock farms, within which grants for the establishment and development of farms (peasant households), were provided. During 201311 beginning farmers and 5 family livestock farms received the state support from the federal and republican budgets totaling 34.57 million rubles (Ministry of agriculture, 2014).

Table 2. Agricultural production in all categories of households (tons)

\begin{tabular}{llllll}
\hline & 2009 & 2010 & 2011 & 2012 & 2013 \\
\hline Grain & 279774 & 101863 & 289920 & 184248 & 158260 \\
Potatoes & 295250 & 159755 & 281222 & 326753 & 314144 \\
Vegetables & 176429 & 140972 & 184373 & 196434 & 178054 \\
Livestock and poultry & 50698 & 55976 & 65375 & 90028 & 119574 \\
Milk & 220403 & 214386 & 200947 & 197518 & 194321 \\
Eggs, thousand & 321856 & 329598 & 333376 & 323547 & 334800 \\
\hline
\end{tabular}

In 2013, the fixed assets of agriculture to invest were 13.6 times more than in 2009 , and 3.8 times more than in 2012 (Sbornik, 2014, p. 22). 
Table 3. Investments in fixed assets by activity "Agriculture, hunting"

\begin{tabular}{|c|c|c|c|c|c|c|}
\hline & 2005 & 2009 & 2010 & 2011 & 2012 & 2013 \\
\hline \multicolumn{7}{|l|}{ Investments in fixed assets } \\
\hline (at current prices), mln. rub. ${ }^{1)}$ & 332.8 & 909.6 & 1330.6 & 2618.4 & 3279.7 & 12369.8 \\
\hline Percentage of total investments & 6.3 & 9.0 & 9.5 & 15.5 & 17.8 & 40.4 \\
\hline \multicolumn{7}{|c|}{$\begin{array}{l}\text { Commissioning of the production } \\
\text { capacity through the construction }\end{array}$} \\
\hline \multicolumn{7}{|l|}{ livestock premises, ths. seats: } \\
\hline for cattle & 3.6 & - & 0.7 & - & - & 0.2 \\
\hline for pigs & 26.0 & 0.7 & - & 15.1 & 1.9 & - \\
\hline for poultry & - & 234.0 & 168.0 & 660.0 & 450.0 & 7500.0 \\
\hline corn and seed storages, ths. tons & 6.2 & - & - & - & - & - \\
\hline potatoes and vegetables, ths. tons & - & - & - & 4,4 & - & - \\
\hline
\end{tabular}

Note. Without small businesses and the volume of investment, not observed by direct statistical methods.

State support for agricultural production in 2013 amounted 1264.893 million rubles, including from the federal budget -992.807 million rubles, the republican budget of the Mari El Republic — 272.086 million rubles.

According to the activity results in 2013 the index of industrial production of food products, including beverages amount to $115.4 \%$ compared to 2012 .

Shipment of goods of own production in the whole production of food products, including beverages, for the year 2013 amounted $120.2 \%$ compared to 2012 .

As of January 1, 2014 for the implementation of the republican target program "Social development of village till 2013" 78,432 million rubles, including from the federal budget-30.4 million rubles, the republican budget of the Mari El Republic - 48.032 million rubles were directed.

Within the framework of the federal purpose-oriented program "Social development of village till 2013" 29.58 $\mathrm{km}$ of gas networks of low pressure, $15.01 \mathrm{~km}$ of local water supply were commissioned in the republic; housing construction in the rural area was 4,796 ths. sq. $\mathrm{m}$.

Gasification level of homes (apartments) with gas network in the rural area was $69.01 \%$, the provision of rural with drinking water supply $-40.6 \%$.

\section{Results}

As for the future development of agriculture in the Mari El Republic, then on the one hand we should expect the expansion of government measures to improve the sustainability of agricultural production and social development of rural areas. On the other hand, difficult macroeconomic environment and the financial and economic crisis may cause restrictions on the use of government support measures.

Taking into account environmental factors in the agricultural sector, climatic conditions of agriculture in the republic and the potential of agro industry, the strategic priorities of its development should be recognized as the development of beef and dairy cattle, meat and dairy industry, poultry and goat breeding, development of fish production, potato and vegetables production.

Diversified growth of the agricultural sector is designed to ensure the development of guinea fowl breeding, horse breeding and processing of these agricultural industries.

Current challenges for regional agro industry are increasing the income of agricultural producers (work on the implementation of the federal law from July 9, 2002 No. 83-FZ "On the financial restructuring of agricultural producers"), the introduction into circulation of unused agricultural land, technical and technological modernization, innovative development, sustainable development of rural areas.

Cluster analysis of major agricultural products in regions of the Volga Federal Region was conducted. The results are shown in Figure 1. 


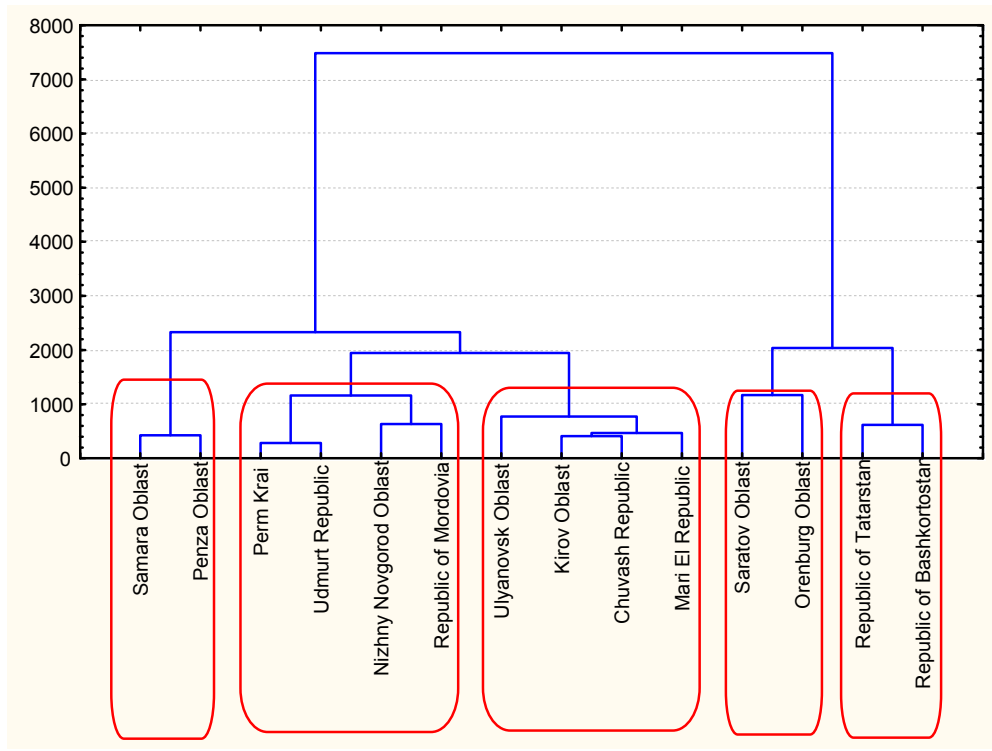

Figure 1. Dendogram of cluster analysis of subjects of the Volga Federal District on the production of basic agricultural products (cattle breeding and plant) in households of all categories in 2013

The results show that the Mari El Republic is stable in the middle group, slightly behind the leaders in the field of agricultural production-Tatarstan and Bashkortostan.

For achieving environmental security of agricultural and food products, it's also important to minimize logistic costs and optimize other factors that determine the competitiveness of agricultural products.

These areas are included in the State program of agricultural development and regulation of agricultural products, raw materials and food in the Mari El Republic for 2013-2020.

Implementation of selected areas of development is assumed by subprograms "Development of the crop sub-sector, processing and marketing of crop production", "The development of the livestock sub-sector, processing and marketing of livestock products", "Development of beef cattle", "Support for small household forms", "Technical and technological modernization, innovative development". It also includes program-targeted tools - republican target programs (for example, "Sustainable development of rural areas for 2014-2017 and for the period up to 2020") and a number of departmental programs of the Ministry of Agriculture and Food of the Mari El Republic.

The study of problems of increasing competitiveness of any enterprise is due to the need to improve the theoretical and methodological foundations of creating a competitive business. Methods of business competitiveness improvement are based on the anticipation of important trends of external market environment of the organization; on the choice of an optimal competitive strategy under the current competitive market structure; on strengthening of the company's position in terms of its interaction and integration with other members of the products distribution channel.

For assessment of the regional market competitiveness the indicators of revenues, expenditures and production volumes are used. In Table 4 the indicators of competitiveness of the food market of the Mari El Republic are considered. 
Table 4. Competitiveness of the food market in Mari El Republic evaluation indicators (Ministry of agriculture, 2014)

\begin{tabular}{|c|c|c|c|c|c|c|c|c|}
\hline \multirow{2}{*}{ Indicators } & \multirow{2}{*}{2010} & \multirow{2}{*}{2011} & \multirow{2}{*}{2012} & \multirow{2}{*}{2013} & \multicolumn{4}{|c|}{ Growth rates (base), $\%$} \\
\hline & & & & & 2010 & 2011 & 2012 & 2013 \\
\hline $\begin{array}{l}\text { The ratio of per capita } \\
\text { income to subsistence level }\end{array}$ & 2.1 & 2.1 & 2.4 & 2.4 & 100.0 & 100.0 & 114.3 & 114.3 \\
\hline $\begin{array}{l}\text { The average monthly } \\
\text { nominal wage (without social } \\
\text { benefits) of employees of } \\
\text { organizations by economic } \\
\text { activity, rub., total } \\
\text { including: }\end{array}$ & 12651 & 14001 & 16023 & 18360 & 100.0 & 110.7 & 126.7 & 145.1 \\
\hline $\begin{array}{l}\text { agriculture, hunting and } \\
\text { forestry }\end{array}$ & 9403.1 & 11096 & 12905 & 14569 & 100.0 & 118.0 & 137.2 & 154.9 \\
\hline $\begin{array}{l}\text { Gross output of agricultural } \\
\text { production, mln. rub. }\end{array}$ & 18642 & 24765 & 25194 & 30232.4 & 100.0 & 132.8 & 135.1 & 162.2 \\
\hline $\begin{array}{l}\text { Retail trade turnover of food, } \\
\text { without tobacco, mln. rub. }\end{array}$ & 20318 & 22794 & 26433 & 31565 & 100.0 & 112.2 & 130.1 & 155.4 \\
\hline $\begin{array}{l}\text { Consumer price indices for } \\
\text { food products }\end{array}$ & 116.7 & 102.7 & 106.6 & 109.5 & 100.0 & 88.0 & 91.3 & 93.8 \\
\hline $\begin{array}{l}\text { Export of food and } \\
\text { agricultural raw materials } \\
\text { (except textile), } \%\end{array}$ & 4.9 & 5.6 & 4.8 & 4.9 & 100.0 & 114.3 & 98.0 & 100.0 \\
\hline $\begin{array}{l}\text { Import of food products and } \\
\text { agricultural raw materials } \\
\text { (except textile), \% }\end{array}$ & 6.7 & 9 & 11.3 & 14.4 & 100.0 & 134.3 & 168.7 & 214.9 \\
\hline
\end{tabular}

In general, the analysis of the regional food market shows a dynamical growth of agriculture. High growth indicators, on the one hand, show the extended type of production in the industry, on the other hand - on the growth of competitiveness of agriculture and its attractiveness as a business. In this case, the basic aim of investors (including foreign), despite the unstable income, is placed on the agricultural business. Significant growth lag of the food market is due to the low solvency of the end user, the residents of the Republic of Mari El, although per capita income for the period under review increased.

Evaluation of the market is reflected in the growth of turnover by types of activity. For four years, the turnover of organizations of all activities reached 51.7 percent growth. In fisheries due to the small scale of the initial activity increase in turnover by 7 times compared to 2010 and an increase in wages by 2.4 times is observed. Increasing turnover was also at wholesale (twice during 4 years) and retail trade - by 33 percent. Volumes of gross agricultural output are also growing. By 2013, four years of growth of gross output was $62 \%$. Extreme changes in increase of production are observed in 2011 (32.8\%) and in 2013 (26.9\%). Activity of business entities shows good pace of business formation and the potential of the agricultural market.

However, the instability of the economy is still existing and it is reflected in the consolidated financial results which is not stable over the years. By 2012, the growth of balance profit has reached $99.7 \%$, and was substituted in 2013 with the decline in earnings from 5299 to 3024 thousand rubles. At the same time a steady growth of balance profit in agriculture is observed. By 2013, it increased by 56 thousand rubles.

Another situation is observed in the manufacturing industry. In 2013, the obtained balanced profit was on $4.8 \%$ lower than in 2010, amounting the minimum during 4 studied years. The downward trend in the number of unprofitable enterprises was replaced in 2013 by their growth.

Agriculture shows a favorable picture - the number of loss-making organizations steadily declined since 2010 by more than 5 times. The same unprofitable enterprises reduction trend was observed in wholesale and retail trade (reduction of a factor is 2 times, compared to the 2010 level).

The rise of prices has a direct impact on the competitiveness of the company offers. The consumer price index in the republic is not stable over the years. The minimum for the specified period was recorded in $2011(102.7 \%)$, 
the maximum in $2010-116.7 \%$. Growth rates in import of foodstuffs and agricultural raw materials exceed the growth rates of export. Import in 2013, compared with a specific weight of 2010 increased by 2.1 times, while the share of exports remained at the 2010 level. This indicator points to the "subsidized" policy of republic's economy. It is needed to develop the internal capacities to ensure the republic with the most necessary goods of agro-industrial complex.

Investment attraction in agro-industrial complex and the formation of the effective investment policy today receive considerable attention, because it is able to become the "catalyst" of economic development as of the state as a whole, as well as of any of its regions or municipality.

Investments are important for the future status of enterprises and for the economy of the country as a whole. With its help the expanded reproduction of fixed assets for production and non-production, material and technical base of business entities that enables enterprises to increase agricultural production, improve living and working conditions of workers are implemented. Cost price, range, quality, originality and attractiveness of products, as well as its competitiveness also depend on investments.

The main principles of the investment policy of Mari El Republic, the implementation of which contributes to the further intensification of investment processes and attracting additional investments to the region are:

1) Active positioning of the Mari El Republic in the Russian and foreign markets; 2) State support of investors (subsidies, grants and tax incentives); 3) The development of public-private partnerships institutions; 4) The combination of a strategic approach, rapid response and program management method based on the results; 5) Ensuring balanced development of the country as a whole and individual industries of economics; 6) Reducing the cost of doing business in the region; 7) Reduction of investment risks associated with investment. 8) The political and financial stability of the society; 9) Energetic efficiency of investments; 10) Staffing and staff motivation.

Solving the problem of increasing investment activity as a factor of economic growth and stabilizing the positive changes in the dynamics of investment in fixed assets is provided by the market mechanism and regulating influence of the government on the investment processes. In this case, government influence on the investment processes is necessary in order to reverse the negative trends, investment unattractive regions and sectors, the passivity of economic entities in the field of investment activities.

The agricultural sector has its own specifics, which essentially depends on the weather conditions, the level of capital turnover, and the elasticity of demand for food. Therefore, agriculture has objectively unequal starting conditions of farming in comparison with other industries. All this leads to the loss of agricultural enterprises, the deterioration of their financial condition, to the emergence of "the effect of price scissors" (price disparity), when the growth of prices for the products of industry is far ahead of the pace of change in prices for agricultural products. The consequence of this condition is the fact that $70 \%$ of fixed assets are fully depreciated. Under such conditions, tax incentives to agriculture should be seen as a necessary government support of the industry.

Currently, there are a number of benefits to stimulate renewal of fixed assets of agricultural enterprises. The major one is a privilege in paying income tax, as the main profit of the company is the overwhelming majority of investments in fixed assets of the enterprise. Thus, according to corporate income tax for agricultural producers, not switched to the taxation system for agricultural producers for activities related to the realization of the own produced agricultural products, as well as to the realization of own produced and processed agricultural products, has a zero rate $(0 \%)$.

Also, in accordance with Art. 284 of the Tax Code of the Russian Federation, 18\% income tax rate to the regional budget can be reduced by the law of subject of the Russian Federation to certain categories of taxpayers. Law of the Mari El Republic on October 27, 2011 No. 59-Z, determines the following benefits to enterprises engaged in investment activities in the Mari El Republic:

- At a rate of investment of $25 \mathrm{mln}$. rub. up to $50 \mathrm{mln}$. rub. rate of tax payable to the budget of the Mari El Republic is $17 \%$;

- At a rate of investment of 50-75 mln. rub.-16\%;

- At a rate of investment of $75-100 \mathrm{mln}$. rub. $-15 \%$;

- At a rate of investment of more than $100 \mathrm{mln}$. rub.-14\%.

This privilege is theoretically designed to encourage investment processes, but in fact it is not completely effective, since the amount of benefits is negligible, and the size of investments for providing benefits is great. In this way, before, until 2002, the stimulating role was mainly served by the income tax. In the period of the Law 
on Corporate Income Tax companies which invested profits in the development of their own production, could benefit from a $50 \%$ investment incentives. This benefit made the development of production profitable for the company.

Another significant exemptions from payment of taxes is a tax exemption on the property of the organization, which is established by normative legal acts of the Russian Federation. So, in the Mari El Republic the tax for agricultural enterprises and farms (peasant households) property is $1.1 \%$ while the basic rate tax is $2.2 \%$.

Since 2009, in the Mari El Republic there is an exempt from property tax for those businesses that implement investment projects with investments worth more than 100 million rubles. This exemption is granted within the project's payback period, but no more than three years from the date of commencement of the tax credit.

The most important tax benefits for agricultural producers in the Mari El Republic are the benefits of the regional taxes-property tax and transportation tax. The rate of property tax (in agriculture) is reduced by $50 \%$ of the common and is $1.1 \%$. For agricultural producers, which implement investment projects worth more than 5 billion rubles the tax rate is set as $0.5 \%$ of the tax base beginning from 2014 . Farms and peasant households are free from paying vehicle tax for trucks which they use in agricultural production.

\section{Conclusion}

To solve the problems of the modern agricultural sector it is necessary to create a support system for investors, a significant part of which can be a set of tax breaks for businesses of agricultural cluster, especially for enterprises of agricultural engineering and processing. Creating favorable conditions for agriculture, reducing its costs and investment risks, the introduction of tax incentives for investment projects determine the strategic foundation for further improving the competitiveness of the agricultural sector.

\section{Acknowledgment}

This article was prepared under a grant of the Russian Humanitarian Foundation (project "Study on the competitiveness of the agricultural sector in the Republic of Mari El" \# 14-12-12001).

\section{References}

Agriculture, hunting and forestry of the Republic of Mari El. (2014). Statistical Sbornik (p. 242). Yoshkar-Ola: Maristat.

Bilson, A., \& Darku, S. (2015). Sources and Measurement of Agricultural Productivity and Efficiency in Canadian Provinces. Crops and Livestock. http://dx.doi.org/10.1111/cjag.12061

Goretov, I. N. (2012). The effectiveness of the development and management of regional poultry clusters. Innovatsionnoe razvitie economiki, 12(6), 13-20.

Gumarova, F. Z., \& Kazakovtseva, M. V. (2014). Development of the mechanism of management of public finances, taking into account the competitive features of the development of the AGRO-INDUSTRIAL COMPLEX of the Republic of Mari El. Sovremennye problem nauki i obrazovanija, 5, 428.

Rakhal, S., \& Shashini, R. (2014). Revealed Comparative Advantage and Half-a-Century Competitiveness of Canadian Agriculture: A Case Study of Wheat, Beef, and Pork Sectors. http://dx.doi.org/10.1111/cjag.12057

Shvetsov, M. N. (2010). Features of the company's strategy in the financial crisis. Aktualnye problrmy gumanitarnych I estestvennych nauk, 9, 160-166.

Smirnov, A. A., \& Popova, E. V. (2011). Investment in agriculture. Vestnik Kazanskogo Agrarnogo Universiteta, $19(1), 65-68$.

The outcome of the agro-industrial complex. (2013). Ministry of agriculture and food of the Mari El Republic. Retrieved from http://mari-el.gov.ru/minselhoz/DocLib1

Tsaregorodtsev, E. I. (2013). Implementation of clustering strategy in development of regional agrarian sector. Diskussija, 40(10), 95-98.

\section{Copyrights}

Copyright for this article is retained by the author(s), with first publication rights granted to the journal.

This is an open-access article distributed under the terms and conditions of the Creative Commons Attribution license (http://creativecommons.org/licenses/by/3.0/). 